\title{
Personality disorders and the risk of violating legal norms - what we know about the complex nature of humans
}

\author{
Beata Pastwa-Wojciechowska $a^{A, B, D, E, F}$ \\ University of Gdansk, Poland
}

The article explores the relationship between theoretical knowledge of the psychology of personality disorders and its practical application in the area of justice. There is agreement in the literature on the relationship between a diagnosis of personality disorder and the increased risk of aggressive or violent behaviour, as pointed out by both the research of clinicians and judiciary workers. Nevertheless, the issue of explaining and understanding the relationship between personality disorders and violence has not yet been resolved, due to conceptualisation, diagnostic, methodological, psychotherapeutic and resocialisation difficulties. These controversies stimulate reflection and an attempt to determine whether the relationship between personality disorders and aggression is the same in all types of personality disorders.

KEY WORDS

personality disorders; crime; practical implications

Corresponding Author - Prof. Beata Pastwa-Wojciechowska, University of Gdansk, 4 Bażyńskiego Str., 80-952 Gdansk, Poland, e-mail: psybpw@ug.edu.pl

AUthors' CONTRIBUtion - A: Study design - B: Data collection - C: Statistical analysis - D: Data interpretation .

E: Manuscript preparation · F: Literature search · G: Funds collection

TO CITE THIS ARTICLE - Pastwa-Wojciechowska, B. (2017). Personality disorders and the risk of violating legal norms -

what we know about the complex nature of humans. Current Issues in Personality Psychology, 5(3), 183-195.

RECEIVED 19.05.2017 · REVIEWED 13.07.2017 • ACCEPTED 13.07.2017 • PUBLISHED 22.09.2017 


\section{BACKGROUND}

The concept of personality disorders is of interest to both theorists and practitioners, because on the one hand it raises a lot of diagnostic, methodological and competence controversies, and on the other hand, clinicians have to deal with it quite frequently in diagnostic, therapeutic and resocialisation work. In the belief of many professionals any person whose behaviour deviates from the recognised "common" pattern reveals traits of a disturbed personality. Therefore, in clinical practice, it can be observed that the assessment of personality places a strong emphasis on attitudes towards applicable social norms, including legal ones, from the assumption that non-observance of these norms is a feature solely of an impaired personality. It is hard not to get the impression that such conduct leads to a too broad recognition of disturbed personality at the expense of narrowing the diversity of personality traits and the wide variability of behaviour depending on the situation and environmental conditions (Pszybysz, 2003). The question then arises as to how contemporary psychological knowledge of personality disorders can be and is used in judicial practice.

Personality disorders differ from other psychopathic conditions by their complexity, as well as a lack of emotional neutrality in their diagnosis. In other words, a diagnosis of having a personality disorder is very often received by those people whose characteristics, style of functioning or consequences of their behaviour lead to violations of legal norms. Therefore, the notion of personality disorders, especially antisocial/psychopathic personality disorders, is often associated or even identified with crime, particularly crime with a high degree of aggression such as murder, rape or robbery (Blackburn \& Coid, 1999; Warren, Hurt \& Loper, 2002; Logan \& Blackburn, 2009; Gilbert \& Dafern, 2011; Pastwa-Wojciechowska, 2008, 2015a, 2015b, 2015c; Cierpiałkowska, 2013). Some authors point out that symptoms of personality disorders appear to be a stronger predictor of its use (such crime) than the category of personality disorders itself (Esbec \& Echeburua, 2010). It is believed that the symptoms of such personality disorders described in sections A and B of DSM (Diagnostic and Statistical Manual of Mental Disorders), such as paranoid, narcissistic, and antisocial, increase the risk of violence. Furthermore, three important principles concerning the relationship between personality disorders and violence are emphasised, namely: a) personality disorders are not a homogeneous diagnostic category; b) among the majority of patients who perpetrate violence and situations involving violence requiring clinical intervention, the co-occurrence of other diagnoses is observed, c) there is a relationship between violence and the risk of violence and the co-occurrence of psychoactive substance dependence (Esbec \& Echeburua, 2010; Pastwa-Wojciechowska, $2015 \mathrm{a}, 2015 \mathrm{~b})$. It is therefore understood that the notion of personality disorders widens our psychological knowledge of the determinants of criminal behaviour, and also creates wider diagnostic possibilities at the interface of psychology and law.

Mechanisms that regulate and integrate behaviours seem to be the common denominator of the dependency between personality disorders and violence, and also a lack of control over one's own behaviour (Pastwa-Wojciechowska, 2008a; Esbec \& Echeburua, 2010; Gilbert \& Daffern, 2011). In the literature, both the concept of emotions and the regulation of emotions are conceptualised in various ways, while in the majority of concepts of emotional regulation the role of processes by which emotional responses are modified to achieve the individual's desirable goals are accentuated. In the case of personality disorders, due to their complexity and heterogeneity, these strategies, on the one hand, depending on the type of personality disorder, will appear different, while on the other they will be disadaptive and dysfunctional (Soroko, 2007; Pastwa-Wojciechowska, 2008a). Dominance of the sense of external control in personality disorders is a reflection of beliefs about the unpredictability of events in the surroundings and the inability to control them, dependencies on random events, other people or various external factors, and the lack of a relationship between behaviour and emerging situations. In other words, individuals with personality disorders perceive their behaviour as out of control and do not believe in the ability to influence events (Jakubik, 2003).

According to A. Jakubik (2003), in personality disorders, the immaturity of regulation and integration mechanisms of human behaviour leads to a lack of or defective self-control. Effective self-control is primarily conditioned by the degree of maturity of the motor-emotional mechanisms and the coherence and balance of cognitive structures, while a precondition for this equilibrium is the appropriate degree of correspondence between "I - real" and "I - ideal". These elements of the pathological structure of "I" as a lowered self-evaluation, low ability to regulate the substructures of "I" and various forms of their differences and ambivalence are a source of tension and anxiety. The undeveloped self-structure of "I" in personality disorders is characterized by: a) an excessive need for control, b) a low level of behavioural control (low complexity, poor differentiation of the subject of impact and the situation, inability to recover lost control), c) ineffective behavioural control, d) low level of cognitive control; e) generalised, unstable and poor sense of control, expressing a lack of sense of security and power, f) increased demand for information confirming behavioural, cognitive and emotional control, g) global rather than divergent char- 
acter of exercised, perceived and potential control, h) a high degree of discrepancy between the different types of controls, i) disruption of the processing of information relating to different types of control, j) a sense of external control (belief that external factors affect events and not behaviour), k) stereotypical use of manipulative mechanisms to maintain or restore a lost sense of control. In turn, deficits of cognitive structures are primarily characterised by a lack of emotional control mechanisms, i.e. the ability to adequately express emotional states (suppression or free display of emotion) depending on the situational context. The mechanism of emotional control is influenced by three factors: 1) properties of the central and peripheral nervous system, 2) emotional reactions learned in the development process, 3) patterns and cultural norms that determine the importance of certain types of emotional behaviour in a given environment. Therefore, the diagnosis of personality disorders is primarily for patients whose problems have a chronic, untreated nature - they raise a sense of helplessness, pessimism and frustration, leading to the transfer onto them of responsibility for the state of affairs.

On the other hand, Baumeister, Heatherton, and Tice (2000) emphasise the role and significance of self-regulation disorders by distinguishing two main categories: under-regulation, where the individual does not control himself, and mis-regulation, where control is exercised but does not produce the desired results or it produces alternative results. These two types of regulation are two different issues, related to different processes, and must be analysed separately. It should be noted, however, that insufficient regulation is an issue that is better known compared to studies on inappropriate regulation.

\section{PERSONALITY DISORDERS AND ADDICTION OR THE RISK OF ALCOHOL ADDICTION}

Since the beginning of research into personality, a predisposition to addiction has been strongly associated with pre-existing and co-occurring personality disorders, both psychopathic and sociopathic, and features characteristic for these disorders, such as impulsivity, hyperactivity, behavioural and emotional disinhibition, sensation-seeking, susceptibility to boredom or generalised difficulty with self-control (Woronowicz, 2009; Pastwa-Wojciechowska, 2015a, 2015b; Poprawa, 2015). Personality disorders often manifest as behaviours risky to health and well-being. Therefore, antisocial personality disorders are associated not only with an increased risk of crime and violence, but also a wider spectrum of negative consequences such as leaving school, homelessness, low socioeconomic status and increased early mor- tality (Coid, 2003; Compton, Conway, Stinson, Colliver, \& Grant, 2006; Esbec \& Echeburua, 2010; Pastwa-Wojciechowska, 2015a, 2015b). These features are also characteristic for people with borderline personality disorders. In other words, a lot of empirical data point to the co-occurrence of behavioural disorders and dissocial/antisocial, and impulsive and borderline personalities, with alcohol problems and alcohol use disorders.

Analysing the relationship between personality disorders and addiction to psychoactive substances, especially alcohol, highlights the central role of emotional regulation processes, both negative and positive (Dragan, 2008, 2016; Poprawa, 2015). The relationship between the regulation of emotions and drinking alcohol in patients with a dyssocial (antisocial) personality is accented (Cloninger, Sigvardsson, \& Bohmann, 2002; Woronowicz, 2009; Chodkiewicz, 2010, 2012; Poprawa, 2015). An interesting hypothesis was proposed by Gorenstein and Newman (1980), who found that psychopathy, antisocial behaviour, impulsive behaviour, alcohol abuse and substance abuse were different manifestations of a more basic disorder called generalised disinhibitory complex. Later studies have shown many correlations supporting this hypothesis. For example, it has been reported that early alcoholism is associated with an increased likelihood of antisocial behaviour and dementia (Cloninger, Sigvardson, Reich, \& Bohman, 1988; Tarter, 1988; McGue, Slutske, \& Iacono, 1999). According to Melibruda and Sobolewska-Melibruda (2006), the mechanism of compulsive emotional regulation is responsible for transforming various emotional states into a desire to consume alcohol - states that are unpleasant and pleasant, that cause tension, attempting to quickly relieve emotional distress or the temptation to re-experience pleasure, ease unpleasant emotions, stress, low level of resistance to suffering, low tolerance of boredom, increased need for stimulation, positive expectations associated with already known effects of alcohol, and narrowing of consciousness leading to a "distraction" from problems and concentration on alcohol. Interestingly, regardless of individual factors that influence the development and persistence of addictions, the personality of alcoholics - as the disease progresses - becomes uniform and independent of the pre-illness image of personality and leads to "personality psychopathy" (Portnov \& Piatnickaja, 1977).

In turn, A. Klimkiewicz, Kimkiewicz, Jakubczyk, Kieres-Solomoński, and Wojnar (2015) noted that some psychotic disorders in predisposed individuals support the development of addiction. These include dyssocial personality disorder, schizophrenia, bipolar affective disorder, anxiety with panic attacks, social phobia, posttraumatic stress syndrome, depression, and hyperactivity with attention deficit disorder. In addition, the presence of psychiatric disorders is as- 
sociated with more frequent use of alcohol in an uncontrolled manner. It was found that the criteria for alcohol dependence were met by about $30 \%$ of people with personality disorders.

The relationship between personality disorders, abuse or addiction to psychoactive substances and violence can lead to several variants of behaviour: 1) aggression is a typical way of acquiring psychoactive drugs; 2) violence (threats, beatings, wounding) can be a way of regulating interpersonal behaviour; 3) psychoactive substance abuse and aggressive (violent) behaviour may have similar conditioning; 4) some psychoactive substances may particularly predispose to aggressive behaviour (Esbec \& Echeburua, 2010). The negative emotions experienced by an addicted person can be triggered by factors such as: a) suspicion, fanaticism, pathological jealousy or the need for revenge (paranoid personality disorder); b) reluctance to have physical contact with others (schizoid personality disorder); c) intolerance of frustration and intense anger over treatment other than expected (narcissistic personality disorder); d) due to the need to release tension associated with the fear of losing a loved one (borderline disorder); e) sense of exclusion or rejection by others (avoidant disorder); f) boredom or need for meaning, lack of empathy (antisocial personality disorder); g) the need for attention or belonging to a group (histrionic and dependent personality disorders); and h) cognitive disorders and bizarre experiences (schizotypal personality disorders). In other words, the use of psychoactive substances is more common in people with personality disorders, with the highest frequency being seen in people from cluster B, especially with anti-social/ psychopathic personality disorders and with borderline disorder (Woronowicz, 2013; Gilbert \& Daffern, 2011; Wayland \& O'Brien, 2013; Poprawa, 2015).

\section{CO-OCCURRENCE OF PERSONALITY DISORDERS WITH OTHER DIAGNOSES}

Personality disorders are highly prevalent among patients, irrespective of their gender, and also cause numerous diagnostic problems due to their association with other psychopathological diagnoses. The following are observed in individuals with personality disorders, a) high rates of co-occurrence of other mental disorders, b) higher rates of psychotic symptoms and psychotic disorders than in patients with other disorders, c) significant psychosocial disorders, d) higher levels of impulsivity compared with those who have no personality disorder, e) higher rates of suicidal thoughts and behaviours than in the general population, which undoubtedly affects the numerous problems and difficulties associated with their diagnoses (Woronowicz, 2009; Błachut, Badura-Brzoza, Jarząb, Gorczyca, \& Hese, 2013; Pastwa-Wojciech- owska, 2015a, 2015b). Studies show that $5-8 \%$ of patients are diagnosed with personality disorders, although this figure may increase to more than $30 \%$ if we take into account the fact that patients may receive a diagnosis of a personality disorder as a co-occurring diagnosis or as an additional diagnosis.

Studies suggest that $30-40 \%$ of outpatient psychiatric patients and $40-50 \%$ of psychiatric patients meet the criteria for one or more personality disorders. On the other hand, in the case of the population of mentally ill male criminals, studies suggest that up to two thirds have been diagnosed with one or more personality disorders. Very often, personality disorders also coexist with such psychiatric disorders as schizophrenia, delusional syndromes, affective disorders or psychoactive addiction (Levinson \& Fonagy, 2004; Esbec \& Echeburua, 2010; Gilbert \& Daffern, 2011).

Coexistence of personality disorders has been met with great interest among researchers in recent years because the etiology and pathogenesis of most personality disorders defined by contemporary psychiatry raise a lot of controversy among clinicians. Therefore, comorbidity is described as a concept that allows a full description of the psychopathology that occurs in a given patient within a given time period. For example, the co-occurrence of alcohol dependence with antisocial/psychopathic personality is highlighted and borderline, personality affective disorders are related to masochistic or narcissistic personality, while some forms of schizophrenia co-occur with schizotypal personality disorder. Due to the overlapping and also mutual penetration of symptoms of various psychiatric disorders, diagnostic and therapeutic procedures are fraught with numerous difficulties and challenges (Cierpiałkowska, 2004; Cierpialkowska \& Soroko, 2014a; Pastwa-Wojciechowska, 2004, 2013). The literature also highlights the potential utility of this category of co-occurrence of disorders in behavioural analysis and therapeutic intervention planning (Wittchen, 1996; Jacobi et al., 2004). The concept of co-occurrence of disorders, as theoretical considerations and clinical and epidemiological studies indicate, may prove extremely useful in analysing the etiology and development of personality disorders.

Co-occurrence of personality disorders with other diagnoses also covers the issue of sexual abuse and sexual dysfunction and paraphilia. Particular emphasis is placed on the co-occurrence of sexual paraphilia with addiction and abuse of psychoactive substances, personality disorders (mainly antisocial/psychopathic, borderline and schizoid personality) and mood disorders (Gałecki, Talarowska, Florkowski, Mossakowska, \& Depko, 2010). A study by J. Haitzman, Lew-Starowicz, Pacholski, and Lew-Starowicz (2014) showed that among those suspected and accused of sexual offenses against juveniles, personality disorder was most frequently diagnosed (16.3\%), whereas 
in Raymond's study the most common diagnosis was depression (over half the group), which may have been caused by the time and place of the study (after the trial, in prison).

It is also apparent that the problem of the co-occurrence of personality disorders with other diagnoses is also connected with the weakness or defects of current medical classification. Grabski and Gierowski (2012) emphasise that the current diagnostic criteria for personality disorders have an absurdly high incidence of the co-occurrence of disorders, which means that most patients meet the criteria for more than one disorder. An attempt to break out of this impasse in clinical practice is the use of the diagnostic category PDNOS (personality disorder not otherwise specified), which reflects the heterogeneous, multi-faceted nature of humanity and its dysfunction. This category was created for those personality disorder symptoms that do not meet the diagnostic criteria for any of the disorders mentioned in DSM A, B, and C classifications. If a clinician finds symptoms of personality disorders that do not correspond to any specific type, then the clinician should classify them as this type of disorder.

\section{PERSONALITY DISORDERS AND VIOLATION OF LEGAL NORMS}

Diagnosis of personality disorders is the most common diagnosis found in both forensic psychiatric and psychological evaluations, as well as in prison. T. E. Hogue (2010) includes the following among symptoms of personality disorders in the context of criminal behaviour: a) frequent mood swings, b) very hostile attitude towards others, c) difficulty controlling behaviour, d) high suspicion, e) lack of feelings, f) turbulent interpersonal relationships, g) callousness, h) variable attitudes toward others, i) low interest in making friendships, j) weak emotional control, k) immediate need for gratification, la) alcohol or psychoactive substance abuse, lb) problems with employment, m) self-harm, n) continually seeking approval, o) focus on routine activities. It is noted that certain types of behaviour related to breaches of legal norms may be related to personality disorders, but the broader spectrum of disorders that may be responsible for such behaviour must be kept in mind. Because in the literature we most often encounter references to the DSM classification, it is worth recalling that in this classification personality disorders are grouped into three clusters: A, B and C.

The common feature of personality disorders that form cluster A are behaviours that are generally described as withdrawn, cool, suspicious or irrational. Therefore, the disorders in this cluster are characterised by strangeness and eccentricity - a paranoid, schizotypal and schizoid personality.
People with B-cluster disorders tend to exhibit theatrical behaviour and excessive emotion, and seek the attention of others, and their mood is turbulent and often shallow. They often experience intense interpersonal conflicts. Therefore, the disorders that are included in this cluster are characterised by their attention-seeking, emotionality and disregard of the consequences of their own actions. This cluster includes antisocial, narcissistic, histrionic and borderline personality disorders. In turn, cluster $\mathrm{C}$ includes disorders characterised by constant tension and anxiety, and it includes avoidant, dependent and obsessive-compulsive personality disorders.

Studies show that people with disorders from cluster B are more likely to violate legal norms and thus receive a conviction. In addition, they also abuse psychoactive substances more frequently, which is an additional factor that significantly increases the use of violence. As Johnson et al. point out (2000), people with A- or B-cluster personality disorders are estimated to have three times higher risk of violent behaviour (Howard et al., 2008). In the case of people with A- and C-cluster personality disorders, no such risk was observed. An increase in the risk of imprisonment was not observed in those with A- and C-cluster disorders (Esbec \& Echeburua, 2010; Gilbert \& Daffern, 2011). The behaviour of people with Aand C-cluster disorders is less severe than those with B-cluster disorders. However, people with A-cluster disorders display increased suspicion, bizarre forms of thinking or social isolation, which may be associated with more serious forms of violence. In turn, people with C-cluster disorders are characterised by submissiveness and strong control of their behaviour, which does not appear to be conducive to violence (Howard, Huband, Duggan, \& Mannion, 2008). It must be borne in mind, however, that behind apparent submission and acceptance, anger and rage may be hidden due to the need to need to give up one's own desires or due to rejection. As a consequence, this group may exhibit acts of violence against people of significance and sexual exploitation, while alcohol addiction will increase the incidence of such behaviour. An analysis of the literature shows that 47 to $69 \%$ of serious violent offenders fulfil diagnostic criteria for at least one of the following personality disorders - antisocial, borderline, narcissistic, and paranoid personality disorder (Coid 2002, 2003; Coid et al., 2006).

\section{ANTISOCIAL PERSONALITY DISORDER/PSYCHOPATHY}

The diagnosis of both antisocial personality disorders and psychopathy is closely related to criminal behaviour, including disregard and violation of others' rights. The high degree of social harm of these 
individuals is due to personality traits and patterns of behaviour such as aggression, violence, manipulation, exploitation of others to meet their own needs, lack of empathy and remorse, and realistic self-assessment (Hare, 1996, 2003, 2006; Pastwa-Wojciechowska, 2004, 2013; Millon \& Davis, 2005; Groth, 2010). Psychopathic behaviour is characterised by negative attitudes towards legal norms on the one hand and the consequences for the psychopath on the other, as well as the consequences for others arising from this fact in the form of recklessness, negligence or complete indifference to the harm done to others. They may neglect to take care of their children, thereby endangering them, which may be manifested by a child's malnourishment, lack of care during illness or lack of care about hygiene, a child's dependency on relatives or neighbours and an incapacity to organise childcare during absences from home. Signs of irresponsibility also include periods of unemployment, giving up jobs without sensible reasons or frequent absences from work. Their behaviour is dominated by rivalry towards others; their goal is survival, so no one can be trusted, morality is illusion, goodness is weakness and trust is naive. They typically use lies and manipulation for pleasure or for personal gain, but the motivation of such behaviours can vary, stemming from the need for power as well as sexual motives (Millon \& Davis, 2005). Psychopaths believe that norms are meant to be broken. They are often in conflict with their own internal system of values, which results from the fact that psychopaths struggle between the sense of autonomy expressed by opposition to the existing order and the desire to influence others.

Impulsivity is manifested in a lack of planning skills because these people make decisions under the influence of impulses, regardless of the consequences of their behaviour. Surviving risk and making discoveries are rewards for them, because they love challenges; they believe that they can cope, that they have the gift of persuasion, and they do not want a quiet life (Oldham \& Morris, 1997). Instead of solving problems, they prefer to take revenge, in fact for their own wrongdoings, and the concept of harm has a very wide range for them. The characteristic feature of this type of personality is an emotional coolness that equates to a lack of experience of such emotions as compassion or guilt. They are not able to understand the suffering of others, hence the ease with which they can inflict drastic mental and physical abuse. Some of them can mask their lack of scruples and empathy, skilfully applying the required verbal communication. In addition, they exhibit a lack of tolerance for frustration, with a very low sense of fear, meaning that punishment and fear do not act as inhibitory factors (Pastwa-Wojciechowska, 2004; Millon \& Davis, 2005).

In the spectrum of research dealing with the influence of psychopathy on aggressive behaviour, two main groups can be distinguished. Firstly, they are analyses of the direct relationships between psychopathy and crime related to violence. These studies usually refer to the relationship between the severity of psychopathy and the various indicators of violence, such as the number of convictions, the number of repeat offences and sentences for specific offences. The second group of studies deals with the analysis of those variables that may mediate in the dependency between psychopathy and aggression or violence. The variables most commonly taken into account here are age, level of anxiety, level of intelligence and social withdrawal (Pastwa-Wojciechowska, 2004; Boduszek, Dhingra, Stander, Ioannou, \& Palmer, 2014).

A significant number of studies confirm that high levels of psychopathy are associated with a higher incidence of aggressive and criminal behaviour, but attention must be paid to the nature of the crimes committed. Due to the strong relationship between psychopathy and the increased risk of crime, including sexual crimes, the variable of psychopathy is present in numerous tools to measure its various aspects, including the risk of recidivism. However, referring to the PCL-R questionnaire, it is worth noting that it was subjected to a comprehensive analysis of its usefulness in predicting the level of risk (Grann, Långström, Tengström, \& Kullgren, 1999; Seto \& Barbaree 1999; Buffington-Vollum, Edens, Johnson, \& Johnson, 2002; Walters \& Heilbrum, 2010). Thus, Dutch studies have shown that criminals diagnosed as psychopathic are more likely to commit further offences (sexual, non-sexual, violent, non-violent, general) than non-psychotic offenders, and that there is a greater likelihood of recidivism among psychopathic offenders with deviant sexual preferences compared to others where this tendency does not occur (Hildebrand, Ruiter, Vogel, \& 2004). Therefore, it is assumed that PCL-R is an important predictor of recidivism in general.

\section{PARANOID PERSONALITY DISORDER}

People with a paranoid personality are characterised by a low degree of trust and a high degree of suspicion towards other people. This disorder often leads to problems at work, as these patients are so sensitive to position and authority that they often have difficulty dealing with superiors and co-workers (Morrison, 2016). The paranoid personality disorder is characterised by a set of six unadaptably enhanced features: suspicion, hostility, autonomy, hypersensitivity, over vigilance and inflexibility, which should be distinguished from both transient states of distrust and systematic delusions of psychotic character (Soroko, 2014). The tendency for suspicion, enmity, and hypersensitivity to others' contempt may provoke violent behaviour (Esbec \& Echeburua, 2010). In the 
population of people violating legal norms, paranoid personality disorder is the second most commonly diagnosed personality disorder in men and the third in women. It most commonly concerns 40-50-yearold men accused of crimes against other persons, and $40 \%$ of criminal cases involving aggression against known persons or accusations of a spouse's infidelity. As Esbec and Echeburua (2010, p. 252) point out, the violent behaviour of a paranoid person is characterised by the following: a) lack of improvisation and rather methodical action to achieve a goal, b) pre-killing signals - a paranoid person normally gives a warning by minor or malicious attacks that should not be ignored or minimised, c) stressful circumstances preceding the offence, and triggering real or imaginary aggression towards their self-esteem; d) motivational factors including revenge, resentment, humiliation, shame and jealousy, e) aggressive behaviour is usually committed individually; f) violent behaviour is unavoidable because a paranoid person feels a kind of duty and therefore does not feel guilty or try to escape, g) the tendency to enter into conflict with the law and behave aggressively even with minimal provocation (real or imagined provocation). In other words, paranoid people commit acts of aggression because of faulty interpretations and overreaction to everyday situations, especially when potential victims try to counteract physical or verbal attacks, which a paranoid person interprets as an attack upon them (Esbec \& Echeburua, 2010). This type of personality is often present in mass and serial killers, soldiers or other people who feel humiliated or underappreciated when doing their jobs or tasks for the benefit of society. Stone (2007) points out that people with paranoid personality disorders who commit violent crimes belong to different subtypes. In some, pathological jealousy dominates, while others show extreme fanaticism and hold persistent thoughts and grudges. This category in particular applies to most perpetrators of mass killings. Almost all mass murderers are male.

\section{BORDERLINE PERSONALITY DISORDER}

People with a borderline personality disorder throughout their adult life appear to be unstable. They experience intense fear of abandonment and inappropriate anger when faced with real separation, or when there is an inevitable change in their plans. Intolerance of loneliness and the constant need to be with other people is linked to the belief that they will not be able to cope alone, and to "survive" they absolutely need other people. During initial meetings they may idealise their partners, constantly requiring them to spend time together and sharing with them the most intimate details of their lives. However, they quickly move from idealisation to devaluation, with the feeling and conviction that these people do not look after them properly or do not handle them adequately. Loneliness causes them great fear and horror, which can lead to self-mutilation or suicide attempts (Cierpiałkowska, 2014).

It should be emphasised that this personality disorder is increasingly diagnosed in the case of people violating legal norms; in the case of men it occupies second place along with paranoid personality disorder, while in the case of women it is in first place. Impulsivity, an identity disorder characterised by chronic, unstable self-image and oscillating from high to low self-esteem, emotional dysregulation and drug use, lead these individuals to violent behaviour.

The brutality of borderline behaviour increases when it is correlated with drug dependence (in 65\% of cases, primarily marijuana, cocaine, alcohol and psychotropic drugs) and with ADHD (in 37\% of cases). Along with antisocial and avoidant personality disorders, this type of disorder is often found in the group of perpetrators of sexual offenses. Borderline people are characterised by a sense of fear, a feeling of abandonment, they have intense and unstable relationships, identity disorders and emotional instability and impulsivity, all of which predispose them to sexual aggression (Esbec \& Echeburua, 2010).

The role and significance of remaining personality disorders in the genesis of aggression and violence that result in violations of legal norms are much less described in the literature. In other words, the remaining personality disorders are more likely to be associated with their co-occurrence with other personality disorders or other psychopathological agents, which can aggravate aggressive behaviour and thereby result in violation of legal norms.

\section{SCHIZOID PERSONALITY DISORDER}

The characteristic feature of schizoid personality disorder is shallowness in emotionality and limited display of both positive and negative emotions. Typically, these are loners who have a limited range of emotions, who give the impression of being asocial and cold (Morrison, 2016). Schizoid people appear calm, without aggression, but in reality they suppress and repel any feelings of anger and aggression, they are unable to express anger and fail to cope with the anger of others. If they express these emotions, it is in the form of passive-aggressive behaviour (March, 2014). In other words, these people are believed not to be aggressive but may exhibit serious attacks of aggression against others, including crimes against sexual freedom.

Mediating factors in aggressive behaviour are fantasies and lack of emotional feelings, including towards other people. According to Stone (2001, 2007, 
see Esbec \& Echeburua, 2010), about $47 \%$ of serial killers meet the criteria for schizoid personality disorders. Withdrawal and indifference to the suffering of others as if the victims were difficult to distinguish from non-living objects are considered to be characteristics predisposing perpetrators of this type of personality disorder to such crimes. This indifference and lack of empathy is also characteristic for people with autistic spectrum disorders (Baron-Cohen, 2003).

In turn, authors such as Gierowski (1989), Majchrzyk (2001), Wolska (2001) and Widacki (2006) note that schizoid personality disorders are most commonly associated with murder, but it is not a large group among the population of this category of perpetrators. Resentment of others can result in negative emotions such as anger and a desire for revenge. Due to the lack of clear and understandable causes of aggression, their behaviour is therefore unpredictable and unexpected. A feeling of rejection can in turn generate suicide attempts.

\section{SCHIZOTYPAL PERSONALITY DISORDER}

These people show persistent deficits in the interpersonal sphere, which causes them to have considerable problems in forming close relationships with others. We can observe in them such qualities as distrust of others and special sensitivity to how they are perceived. They may be suspicious and superstitious, show a tendency towards abstract and speculative thinking, an interest in occultism, extrasensory perception and supernatural powers, as well as an indifference to norms and social conventions. Symptoms of this disorder include continuous emersion in emotions of danger, fear and rage, extreme sensitivity to rejection and loss of sympathy as well as a tendency for cognitive disorganisation under stressful conditions (Pasikowski, 2014; Morrison, 2016).

This disorder is very rarely reported in the population that violates legal norms, but as Esbec and Echeburua (2010) note, a relatively high proportion (25-44\%) are misdiagnosed as schizophrenic. If they commit crimes, they do so by themselves, characterised by a lack of clear motivation, impulsivity and lack of planning. The motivation for these crimes can be bizarre, messianic, or result from magical or illusory thoughts, which makes this type of behaviour very difficult to predict. Victims are often known family members or carers (Esbec \& Echeburua, 2010).

\section{NARCISSISTIC PERSONALITY DISORDER}

The characteristics of narcissistic personality are at the basis of almost all types of violent crime; howev- er, diagnosis of narcissistic personality disorders is rare, especially in connection with other personality disorders.

In people with narcissistic personality disorders, we observe identity disorders that manifest themselves in excessive concern for others in order to underline their own identity and regulate their self-esteem. Self-esteem may be inflated or understated depending on the behaviour of others, while emotional regulation reflects variation in self-esteem. Disorders in interpersonal functioning include impairment in the ability to feel empathy or recognise the feelings and needs of others, and overestimation or underestimation of one's own influence on others. Relationships with others are largely superficial, and they exist to regulate self-esteem and satisfy their own needs. In addition, they serve to emphasise their sense of greatness, their conviction of having special powers, being unique, and being better than others (Gościniak, 2014).

It is understood that features such as authoritarianism and exploitation of others are strongly associated with aggression. Although this disorder occurs in the population of people violating legal norms, its prevalence is in the range of $6-25 \%$, most commonly occurring in the group of sexual offenders and perpetrators of violence against others. Their criminal behaviour may stem from their belief that others are obliged to meet their needs, as well as from their belief that others are merely tools to achieve their goals. The victims of violent acts of narcissistic perpetrators are known to them (Esbec \& Echeburua, 2010). Their violent reactions are a response to their wounded Ego and a response to their psychopathic personality. Narcissism is a common feature in all kinds of violence, especially in antisocial and psychopathic individuals, who primarily seek to satisfy their desires and needs and disregard the rights of others.

\section{HISTRIONIC PERSONALITY DISORDER}

Histrionic people feel discomfort when they are not at the centre of attention, which in the opinion of many researchers is considered to be the most diagnostic criterion (Groth, 2014). In other words, the stronger the discomfort, the more they try to impress others and focus the attention of others on themselves. On the other hand, if these actions do not produce the expected results, they try to gain attention by theatrical and dramatic behaviour. The experience of a loss of admiration from others, and with that a sense of self uniqueness and value, arouses anger, jealousy or despair in them. These people do not handle frustration well, they are unable to defer satisfaction and are also willing to seek immediate gratification. Boredom and a constant search for sensation may lead them into conflicts with the law (Morrison, 2016; Mil- 
lon, Grossman, Millon, Meagher, \& Ramnath, 2004; Groth, 2014). Esbec and Echeburua (2010) point out that the behaviour of histrionic individuals can lead to misperception, emotional over-reactivity, variable emotional states, and a sense of humiliation.

Brutal behaviour occurs when in such a person there is a co-occurrence of histrionic personality disorder with antisocial or narcissistic personality disorder. Esbec and Echeburua (2010) report that this disorder sometimes occurs in anti-social gang leaders, in whom problems with adjusting their behaviour to the standards in force and an inability to cope with stress are observed, and who at the same time have the ability to focus attention on themselves and manipulate others. Thanks to this, they are able to involve other people in aggressive or even criminal behaviour.

\section{OBSESSIVE-COMPULSIVE PERSONALITY DISORDER}

Violence in this personality disorder is rarely reported, but may occur in situations where these individuals experience loss of control and anger, usually associated with alcohol abuse. Basically, these people express "soft" feelings, although they can quite freely express anger, frustration and irritation. Obsessive-compulsive disorder often coexists with other psychiatric disorders, the most common of which are anxiety disorders, social phobias, affective disorders and schizophrenia.

Anger in response to a lack of tolerance for criticism, humiliation or failure is a factor conducive to the development of aggressive or violent behaviour. Acts of violence are made against those known to them. Therefore, they may be accused of chauvinism, violence or harassment of others. As reported by Esbec and Echeburua (2010) in a study of violence against partners, the percentage of people with this type of personality disorder was $57.8 \%$. This may be due to the fact that these people strive for perfectionism and are excessively meticulous, which can put pressure on others to follow their habits.

\section{DEPENDENT PERSONALITY DISORDER}

The most characteristic feature of this personality disorder is the fixed and excessive need for experiencing care that leads to subdued behaviours and causes separation anxiety. Therefore, in situations where they feel abandoned, they may attempt suicide or express violence against the person who rejected them. Also a strong sense of uncertainty and jealousy can produce emotional states such as rage that can lead to them, in extreme cases, to kill and sometimes commit suicide. People with this type of personality disorder, due to their need for belonging and self-esteem, when under the influence of psychopathic individuals may become a tool in their hands and commit violent crimes.

A dependent personality often coexists with such disorders as mood disorders and anxiety disorders. People with this type of personality disorder often have somatization disorder and somnolence, with medical care becoming a major source of support (Górska, 2014).

\section{AVOIDANT PERSONALITY DISORDER}

This type of personality disorder, along with antisocial personality disorder and borderline personality disorder, often occurs among perpetrators of sexual violence. These people often have feelings of revenge against women because they are not able to form satisfying relationships with them because of fear of being ridiculed or rejected.

These people are characterised by a lack of confidence, uncertainty and inferiority. They are afraid that they will be humiliated by others when they reveal their true "I", and therefore feel a strong fear of entering into relationships in the absence of an assurance of uncritical acceptance. They show excessive sensitivity to criticism and rejection, and a strong fear of entering into relationships with others. However, they can also experience impulsive hostility and more aggressive reactions. In other words, they can attack others when they feel that their emotional needs have not been recognised. Victims are most often people known to them, who in the perpetrator's feeling have rejected them, or strangers, who symbolise real or imagined rejection.

\section{SUMMARY}

One way to understand personality disorders is to look at them as non-adaptive ways of adapting to a difficult life situation. As indicated above, violent crimes can be associated with any personality disorder. Personality disorders that are overrepresented in criminal behaviour as well as those that form a basis for violent crime include antisocial, paranoid, narcissistic and borderline personality disorders. As noted above, individuals with C-cluster personality disorders, such as dependence, avoidance and obsessive-compulsive disorder, are significantly less likely to commit violent crimes, but does not mean that they do not commit them at all. According to RD Hare (2003), psychopaths may represent $1 \%$ of the general population, while in the population of those with convictions their proportion is estimated at 10 to $30 \%$. Their proportion even rises to more than $50 \%$ for serious violence and in the case of serial killings 
up to $90 \%$ (Stone, 2001, 2007; Pastwa-Wojciechowska, 2004). It is worth pointing out that among the perpetrators of serial sexual murder, half of them exhibit schizoid personality disorder alongside psychopathic and sadistic disorders (Stone, 2001). Personality disorders are considered to be of major importance in the etiology of criminal behaviour; however, the role and significance of antisocial and psychopathic personality disorders are well defined, bypassing or limiting the importance of other types of disorder (Hart, 1998; Pastwa-Wojciechowska, 2004).

As can be seen, there are many issues that may be relevant in explaining and evaluating the criminal behaviour of individuals with personality disorders. Undoubtedly, it is important to look for factors or mechanisms common to the explanation of personality disorders and their relation to the possibility or the higher probability of violating legal norms; however, the different meaning depending on the personality disorder should be borne in mind. An additional issue affecting the behaviour of individuals with personality disorders and complicating the correctness of diagnosis is co-occurrence of other psychopathology disorders.

Contemporary justice is increasingly using psychological knowledge with the expectation that it will help in making objective and accurate judgments. It is important to realise that the effectiveness of a psychologist depends on good specialist knowledge as well as knowledge of the practice of the justice system.

\section{RefERENCES}

Baron-Cohen, S. (2003). The essential difference: The Truth about the Male \& Female Brain. New York: BasicBooks.

Baumeister, R. F., Heatherton, T. F., \& Tice, D. M. (2000). Utrata kontroli. Jak i dlaczego tracimy zdolność samoregulacji [Losing Control: How and Why People Fail at Self-Regulation]. Warszawa: Państwowa Agencja Rozwiązywania Problemów Alkoholowych.

Blackburn, R., \& Coid, J. W. (1999). Empirical clusters of DSM-III personality disorders in violent offenders. Journal of Personality Disorders, 13, 18-34.

Błachut, M., Badura-Brzoza, K., Jarząb, M., Gorczyca, P., \& Hese, R. T. (2013). Podwójna diagnoza u osób uzależnionych lub szkodliwie używających substancji psychoaktywnych [Dual diagnosis in addicts or harmful use of psychoactive substances]. Psychiatria Polska, 2, 335-352.

Boduszek, D., Dhingra, K., Stander, C., Ioannou, M., \& Palmer, D. (2014). Latent classes of criminal intent associated with criminal behaviour. Currrent Issues in Personality Psychology, 2, 92-102.

Buffington-Vollum, J., Edens, J. F., Johnson, D. W., \& Johnson, J. K. (2002). Psychopathy as a predic- tor of institutional misbehavior among sex offenders: A retrospective replication. Criminal Justice and Behavior, 29, 497-511.

Cierpiałkowska, L. (2004). Psychologia zaburzeń osobowości. Wybrane zagadnienia [Psychology of personality disorders. Selected issues]. Poznań: Wydawnictwo Naukowe UAM.

Cierpiałkowska, L. (2013). Personality disorders in DSM classifications. Current Issues in Personality Psychology, 1, 1-10.

Cierpiałkowska, L. (2014). Zaburzenia osobowości borderline [Borderline Personality disorder]. In L. Cierpiałkowska \& E. Soroko (eds.), Zaburzenia osobowości. Problemy diagnozy klinicznej [Personality disorders. Problems of clinical diagnosis] (pp. 171-197). Poznań: Wydawnictwo Naukowe AUM. Cierpiałkowska, L., \& Soroko, E. (eds.). (2014a). Zaburzenia osobowości. Problemy diagnozy klinicznej [Personality disorders. Problems of clinical diagnosis]. Poznań: Wydawnictwo Naukowe AUM.

Chodkiewicz, J. (2010). Nadużywanie alkoholu przez młodych mężczyzn i młode kobiety - znaczenie czynników temperamentalnych i charakterologicznych [Alcohol abuse by young men and young women - the importance of the teperamental and characterological factors]. Czasopismo Psychologiczne, 16, 181-188.

Chodkiewicz, J. (2012). Odbić się od dna. Rola jakości życia w przebiegu i efektach terapii osób uzależnionych od alkoholu [Bounce from the bottom. The role of quality of life and the effects of therapy of people addicted to alcohol]. Łódź: Wydawnictwo Uniwersytetu Łódzkiego.

Cloninger, C. R., Sigvardson, S., Reich, T., \& Bohman, M. (1988). Childhood personality predicts alcohol abuse in young adults. Alcoholism: Clinical and Experimental Research, 12, 494-505.

Cloninger, C. R., Sigvardsson, S., \& Bohmann, M. (2002). Typ I i typ II alkoholizmu - uaktualnienie badań [Alcoholism typ I and II - Upgrade researches]. In Typologia alkoholizmu [Typology of alcoholism] (pp. 50-64). Warszawa: PARPA.

Coid J. (2002). Personality disorders in prisoners and their motivation for dangerous and disruptive behaviour. Criminal Behaviour and Mental Health, 12, 209-226.

Coid, J. (2003). Epidemiology, public health and the problem of personality disorder. British Journal of Psychiatry, 182, 44, 3-10.

Coid, J., Yang, M., Roberts, A., Ullrich, S., Moran, P., Bebbington, P., ...Singleton, N. (2006). Violence and psychiatric morbidity in the national household population of Britain: public health implications. British Journal of Psychiatry, 189, 12-19.

Compton, W. M., Conway, K. P., Stinson, F. S., Colliver J. D., \& Grant, B. F. (2005). Prevalence, correlates, and comorbidity of DSM-IV antisocial personality syndromes and alcohol and specific drug use disor- 
ders in the United States: results from The National Epidemiologic Survey of Alcohol and Related conditions. Journal of Clinical Psychiatry, 66, 677-685.

Dragan, M. (2008). Doświadczenia traumatyczne a uzależnienie od alkoholu [Traumatic expiriences and alcohol dependence]. Warszawa: Wydawnictwo Uniwersytetu Warszawskiego.

Dragan, M. (2016). Problemowe picie alkoholu przez mtode kobiety. Rola niekorzystnych doświadczeń i samoregulacji emocji [Problem drinking of alcohol by young women. The role of the bad experiences and self regulation of emotions]. Warszawa: Wydawnictwo Naukowe Scholar.

Esbec, E., \& Echeburua, E. (2010). Violence and personality disorders: clinical and forensic implications. Actas Esp Psiquiatr, 38, 5, 249-261.

Fonagy, P, \& Levinson, A. (2004). Offending and attachment: The relationship between interpersonal awareness and offending in a prison population with psychiatric disorder. Canadian Journal of Psychoanalysis, 12, 225-251.

Gałecki, P., Talarowska, M., Florkowski, A., Mossakowska, J., \& Depko, A. (2010). Problemy kliniczne w terapii zaburzeń preferencji seksualnych cześć druga [Clinical issues in the therapy of the sexual preferences disorders - part two]. Current Problems of Psychiatry, 11, 3, 187-192.

Gierowski, J. K. (1989). Motywacja sprawców zabójstw [Killers motivation]. Kraków: Wydawnictwo AM.

Gilbert, F., \& Daffern, M. (2011). Illuminating the Relationship Between Personality Disorder and Violence: Contributions of the General Aggression Model. Psychology and Violence, 1, 3, 230-244.

Gorenstein, E. E., \& Newman, J. P. (1980). Disinhibitory psychopathology: A new perspective and a model for research. Psychological Review, 87, 301-315.

Gościniak, J. (2014). Narcystyczne zaburzenie osobowości [Narcisstic Personality Disorder]. In L. Cierpiałkowska \& E. Soroko (eds.), Zaburzenia osobowości. Problemy diagnozy klinicznej (pp. 171-197). Poznań: Wydawnictwo Naukowe AUM.

Górska, D. (2014). Zależne zaburzenie osobowości [Dependent personality disorder]. In L. Cierpiałkowska \& E. Soroko (eds.), Zaburzenia osobowości. Problemy diagnozy klinicznej [Personality disorders. Problems of clinical diagnosis] (pp. 256-276). Poznań: Wydawnictwo Naukowe AUM.

Grabski, B., \& Gierowski, J. K. (2012). Personality disroders - different outlooks and attempts at their integration. Psychiatria Polska, 5, 829-844.

Grann, M., Långström, N.,Tengström, A., \& Kullgren, G. (1999). Psychopathy (PCL-R) predicts violent recidivism among criminal offenders with personality disorders in Sweden. Law and Human Behavior, 23, 205-217.

Groth, J. (2010). Oblicza psychopatii. Obraz kliniczny i kategorie diagnostyczne [Faces of psychopa- thy. Clinical picture and diagnostic categories]. Warszawa: Wydawnictwo Naukowe Scholar.

Groth, J. (2014). Histrioniczne zaburzenie osobowości [Histrionic personality disorder]. In L. Cierpiałkowska \& E. Soroko (eds.), Zaburzenia osobowości. Problemy diagnozy klinicznej (171-197). Poznań: Wydawnictwo Naukowe AUM.

Hare, R. D. (1996). Psychopathy: A clinical construct whose time has come. Criminal Justice and Behavior, 23, 25-54.

Hare, R. D. (2003). Hare PCL-R ( $2^{\text {nd }}$ ed.). Toronto: Multi-Health Systems.

Hare, R. D. (2006). Psychopaty: A clinical of forensic overview. Psychiatric Clinics of North America, 29, 3, 709-724.

Hart, S. D. (1998). The role of psychopathy in assessing risk for violence: Conceptual and methodological issues. Legal and Criminological Psychology, 3, 121-137.

Heitzman, J., Lew-Starowicz, M., Pacholski, M., \& Lew-Starowicz, Z. (2014). Wykorzystywanie seksualne dzieci w Polsce - analiza badań 257 sprawców, którzy popełnili przestępstwa seksualne wobec małoletnich [Children sexual abuse in Poland - study of 257 sexual offenders against minors]. Psychiatria Polska, 48, 1, 105-120.

Hildebrand M., de Ruiter C., \& de Vogel V. (2004). Psychopathy and Sexual Deviance in Treated Rapists: Association With Sexual and Nonsexual Recidivism. Sexual Abuse: A Journal of Research and Treatment, 16, 1, 1-24.

Hogue, T. E. (2010). Personality disorder classification in forensic settings. In J. M. Brown \& E. A. Campbell (eds.), The Cambridge Handbook of Forensic Psychology (pp. 267-275). Cambridge: Cambridge University Press.

Howard, R. C, Huband N., Duggan C., \& Mannion, A. (2008). Exploring the link between personality disorder and criminality in a community sample. Journal of Personality Disorder, 22, 589-603.

Jacobi, F., Wittchen, H. U., Hölting, C., Höfler, M., Pfister, H., Müller, N., \& Lieb, R. (2004). Prevalence, co-morbidity and correlates of mental disorders in the general population: results from the German Health Interview and Examination Survey (GHS). Psychological Medicine, 34, 1-15.

Jakubik, A. (2003). Zaburzenia osobowości [Personality disorders]. Warszawa: PZWL.

Johnson J. G., Cohen P., Smailes E., Kasen S., Oldham J. M., Skodol A. E., \& Brook J. S. (2000). Adolescent personality disorders associated with violence and criminal behavior during adolescence and early adulthood. American Journal of Psychiatry, 157, 1406-1412.

Klimkiewicz, A., Kimkiewicz, J., Jakubczyk, A., Kieres-Solomoński, I., \& Wojnar, M. (2015). Współwystępowanie uzależnienia od alkoholu z innymi zaburzeniami psychicznymi. Część I. Epi- 
demiologia podwójnego rozpoznania [Comorbidity of alcohol dependence with other psychiatric disorders. Part I. Epidemiology of dual diagnosis]. Psychiatria Polska, 49, 2, 265-275.

Logan, C., \& Blackburn, R. (2009). Mental disorder in violent women in secure settings: Potential relevance to risk for future violence. International Journal of Law and Psychiatry, 32, 31-38.

Majchrzyk Z. (2001). Nieletni, mtodociani i dorośli sprawcy zabójstw [Adolescent, Juvenile and adult murderers. Analysing motivational processes and personality diposiitions]. Warszawa: IPiN.

Marszał, M. (2014). Schizoidalne zaburzenie osobowości [Schizoid personality disorder]. In L. Cierpiałkowska \& E. Soroko (eds.), Zaburzenia osobowości. Problemy diagnozy klinicznej [Personality disorders. Problems of clinical diagnosis] (pp. 118-139). Poznań: Wydawnictwo Naukowe UAM.

McGue, M., Slutske, W. \& Iacono, W. G. (1999). Personality and substance use disorders: II. alcoholism versus drug use disorders. Journal of Clinical Psychology, 67, 394-404.

Mellibruda, J., \& Sobolewska-Mellibruda, Z. (2006). Integracyjna Psychoterapia Uzależnień. Teoria i praktyka [Integrative psychotherapy of dependences. Theory and practice]. Warszawa: IPZ PTP.

Millon, T., \& Davis, R. (2005). Zaburzenia osobowości we wspótczesnym świecie [Personality disorders in modern life]. Warszawa: Instytut Psychologii Zdrowia.

Millon, T., Grossman, C., Millon, C., Meagher, S., \& Ramnath, R. (2004). Personality Disorders in Modern Life ( $2^{\text {nd }}$ ed.). Hoboken: John Wiley and Sons.

Morrison, J. (2016). DSM-5® bez tajemnic. Praktyczny przewodnik dla klinicystów [DSM-5. Made Easy. The Clinician's Guide to Diagnosis]. Kraków: Wydawnictwo Uniwersytetu Jagiellońskiego.

Oldham, J. M., \& Morris, L. B. (1997). Twój psychologiczny autoportret. Dlaczego czujesz, kochasz, myślisz, dziatasz wtaśnie tak? [The New Personality Self-Portrait: Why You Think, Work, Love and Act the Way You Do]. Warszawa: Jacek Santorski \& Co.

Pasikowski, T. (2014). Schizotypowe zaburzenie osobowości [Schizotypal personality disorder]. In L. Cierpiałkowska \& E. Soroko (eds.), Zaburzenia osobowości. Problemy diagnozy klinicznej [Personality disorders. Problems of clinical diagnosis] (pp. 171-197). Poznań: Wydawnictwo Naukowe UAM.

Pastwa-Wojciechowska, B. (2004). Naruszanie norm prawnych w psychopatii. Analiza kryminologiczno-psychologiczna [Psychopathy and lawbreaking. Criminological and psychological analysis]. Gdańsk: Wydawnictwo Uniwersytetu Gdańskiego.

Pastwa-Wojciechowska, B. (2008a). Psychopatyczne zaburzenia osobowości a problemy opiniowania sądowo psychologicznego w sprawach karnych [Psychopathic personality disorders and psychological problems and legal assessment in criminal matters]. Gdańskie Studia Prawnicze, 19, 205-224.

Pastwa-Wojciechowska, B. (2008b). Samoregulacja i samokontrola a psychopatyczne zaburzenia osobowości [Self-regulation and self-control and psychopatic personality disorders]. Czasopismo Psychologiczne, 14, 247-254.

Pastwa-Wojciechowska, B. (2013). Psychopaci. Sprawcy przestępstw seksualnych [Psychopaths. Perpetrators of sexual offences]. Gdańsk: Wydawnictwo Harmonia.

Pastwa-Wojciechowska, B. (2015a). Użyteczność pojęcia zaburzeń osobowości w opiniowaniu sądowo-psychologicznym [The usefulness of the concept of personality disorders in the evaluation of court proceedings as well as the psychological]. In D. Rode (ed.), Modele psychologicznego opiniodawstwa w sprawach karnych [Psychological models ofexpertises in criminal law] (pp. 75-93). Gdańsk: GWP.

Pastwa-Wojciechowska, B. (2015b). Zaburzenia osobowości a perspektywa opiniowania sądowo-psychologicznego [Diagnosis of personality disorder and issues from psychological assessment for forensic perspective]. Polskie Forum Psychologiczne, 4, 499-513.

Pastwa-Wojciechowska, B. (2015c). Zaburzenia osobowości - problem czy nowe spojrzenie na ich rolę i znaczenie $w$ procesie resocjalizacji [Personality disorder is a problem or a new look on their role and importance in the process of rehabilitation]. In A. Kieszkowska (ed.), Prawda-Dobro-Piękno. Wymiar filozoficzno-prawny i socjopedagogiczny [The Truth-Goodness-Beauty. The dimension of philosophy and legal and socjopedagogy] (pp. 328-336). Warszawa: Difin.

Poprawa, R. (2015). Skazani na problemy? W poszukiwaniu osobowościowych uwarunkowań angażowania się mężczyzn w picie alkoholu [Stuck on problems? In search of personal circumstances to engage men in drinking alcohol]. Warszawa: Wydawnictwo Naukowe Scholar.

Portnow, A. A., \& Piatnickaja, I. N. (1977). Klinika alkoholizmu [Clinical aspects of alcoholism]. Warszawa: PZWL.

Przybysz, J. (2003). Psychiatria sqdowa [Forensic Psychiatry]. Toruń: Fundacja TUMULT.

Seto, M. C., \& Barbaree, H. E. (1999). Psychopathy, treatment behaviour and sex offender recidivism. Journal of Interpersonal Violence, 14, 1235-1248.

Soroko, E. (2007). Regulacja emocji w kontekście rozwoju osobowości [Regulation of emotions in growth aspects of personality]. In $Ł$. Kaczmarek \& A. Stysz (eds.), Serce $i$ umyst [Heart and Mind] (pp. 55-80). Poznań: Wydawnictwo Naukowe UAM. Soroko, E. (2014). Paranoiczne zaburzenie osobowości [Paranoid personality disorder]. In L. Cierpiał- 
kowska \& E. Soroko (eds.), Zaburzenia osobowości. Problemy diagnozy klinicznej [Personality disorders. Problems of clinical diagnosis] (pp. 96-117). Poznań: Wydawnictwo Naukowe UAM.

Stone, M. H. (2001). Serial sexual homicide: Biological, psychological, and sociological aspects. Journal of Personality Disorders, 15, 1-18.

Stone, M. H. (2007). Violent crimes and their relationship topersonality disorders. Personality and Mental Health, 1, 138-153.

Tarter, R. E. (1988). Are there inherited behavioral traits that predispose to substance abuse? Journal of Consulting and Clinical Psychology, 56, 189-196.

Walters, G. D., \& Heilbrum, K. (2010). Violence Risk Assessment and Facet 4 of the Psychopathy Checklist: Predicting Institutional and Community Aggression in Two Forensic Samples. Assessment, 17, 2, 259-268.

Warren J. I., Hurt S., \& Loper A. B. (2002). Psychiatric symptoms, history of victimization, and violent behavior among incarcerated female felons: An American perspective. International Journal of Law and Psychiatry, 25, 129-149.

Wayland, K., \& O'Brien, S. D. (2013). Deconstructing Antisocial Personality Disorder and Psychopathy: A Guidelines-Based approach to prejudicial Psychiatric Labels. Hofstra Law Review, 42, 519-588.

Widacki, J. (2006). Zabójstwo z motywów seksualnych: stadium przypadku [Murder with sexual motivation: case study]. Kraków: Krakowskie Towarzystwo Edukacyjne, Oficyna Wydawnicza AFM.

Wittchen, H. U. (1996). Critical issues in the evaluation of comorbidity of psychiatric disorders. British Journal of Psychiatry Suppl, 30, 9-16.

Wolska, A. (2001). Model czynników ryzyka popetnienia zabójstwa [Model of risk factors in murder]. Szczecin.

Woronowicz, B. (2009). Uzależnienia. Geneza, terapia, powrót do zdrowia [Dependences. Genesis, therapy, come back to health]. Poznań: Wydawnictwo Media Rodzina. 